\title{
THE INDEPENDENT LABOUR PARTY AND PLANNING, $1920-26$
}

The failure of the ILP to convince a Labour opposition, and then a Labour government after 1929, to abandon its view that banking and politics were quite separate fields of activity is well-known. Politicians were not bankers: it was as simple as that. Ramsay MacDonald, though not averse to political programmes as such, was certainly suspicious of "unauthorised" programmes. In a veiled but unmistakable reference to ILP policy statements, he told the 1927 Labour Party conference that

"authorised programmes might have a certain number of inconveniences, but unauthorised programmes had many more inconveniences, and he was not at all sure that during the last twelve months or two years the Labour Party had not suffered more from unauthorised programmes and statements than it had suffered from the issue of well-considered and well-thought-out documents and pronouncements." 1

Philip Snowden was much more explicit. Unlike Sir Montagu Norman, Governor of the Bank of England,"2 Snowden did recognise a causal relationship between changes in the availability of credit and changes in the levels of production and employment, but thought that this was a relationship which politicians should not interfere with. Control of credit held within it the possibility of inflation. "It might be highly dangerous", Snowden warned the 1928 Labour Party conference, "in the hands of a Government that wanted to use this means in order to serve some purpose, or to gain popular support." One might achieve temporary benefits, such as the reduction of unemployment from one

1 Labour Party, Conference Report 1927, p. 182.

2 For Norman's views see S. Pollard, The Development of the British Economy, 1914-1950 (London, 1967), p. 220; R. Skidelsky, Politicians and the Slump (London, 1967), pp. 13-14; and D. Winch, Economics and Policy (London, 1969), pp. 89-90. 
and a quarter million to a quarter of a million in nine months, but there would be a terrible price to pay later - all the more terrible because unspecified. ${ }^{1}$

What perhaps is less well-known than this refusal of the Labour Party leadership to be persuaded of the desirability of the ILP's Living Wage policy, is the content of the policy itself, and in particular the fact that at its core was advocated a system of national economic planning. This essay seeks to elucidate the development of the Living Wage policy in this respect.

Towards the close of the First World War, and indeed during the two years that followed its end, the ILP had been unwilling "to prepare elaborate schemes of reconstruction" because "of the unsettled state of industry and of finance and economics". ${ }^{2}$ Beginning in 1920 the doctrine of the ILP was to develop in two increasingly converging directions, each of which was to lead to a concept of planning. First, from the point of view of ultimate demands, the appropriate forms of public control of industry were discussed, in which the approach was, at least initially, a modification of the guild-socialist position which had been much publicised during the previous decade. Secondly, from the point of view of immediate purposes, proposals were developed to lift the depression through a process of redistribution of incomes workers could be paid a "living wage" immediately, without waiting until the whole, or a major part, of industry was socialised. Each approach varied in detail, but both eventually stressed the need for deliberate planning of economic and industrial activity, in which a crucial role would be allotted to the public control of investment and credit.

I

\section{THE SOCIALISATION OF INDUSTRY}

The ILP did not possess, at the end of the First World War, any document similar to the Labour Party's Labour and the New Social Order. ${ }^{3}$ The war was not, however, without effect on the party. In the first place, it provided a political home for many who could not forgive the Liberal Party, not only for taking Britain into the war, but for using certain measures to fight it, especially conscription, and also for pressing unconditional surrender upon Germany rather than

1 Labour Party, Conference Report 1928, p. 231; Winch, op. cit., p. 93, incorrectly attributes this speech to the 1929 Labour Party conference.

2 ILP, Conference Report 1918, p. 32.

3 See A. Oldfield, "The Labour Party and Planning - 1934 or 1918?", in : Bulletin of the Society for the Study of Labour History, No 25 (1972). 
seeking a negotiated peace. ${ }^{1}$ Their entry into the ILP, as well as the war experiences of those who were already members, did much to turn the attention of the party towards foreign affairs, both its aims and its methods of conduct, which had hitherto been somewhat neglected. Of those, however, who were to be prominent in shaping the ILP's domestic policy in the 1920's - Clifford Allen, Fenner Brockway, Fred Jowett, H. N. Brailsford, Frank Wise, and J. A. Hobson - all except Hobson were pre-war members of the party. This is not to suggest that they carried with them, unchanged from pre-war days, policies which became the ILP's after the war. On the contrary, the war had a profound effect on their thinking. The protest they made, especially in the No-Conscription Fellowship, founded by Brockway and largely run by Allen, was a response to the "autocracy of the centralised state". ${ }^{2}$ The sense of powerlessness in the face of an unchallengeable state is well illustrated by the interrogation of Allen by the tribunal which heard his appeal against service on conscientious grounds, during which he regretted that the mere business of living smoking, eating, travelling - assisted the government's war effort by providing it with revenue. ${ }^{3}$ This was fertile ground in which ideas of guild socialism could grow.

Clifford Allen's own conversion on this score would have been of less account had not many in the ILP thought likewise: 805 of the 1091 conscientious objectors tried were members of the ILP. ${ }^{4}$ The ILP itself, thus, was prepared for doctrines, like those of guild socialism, which would minimise the competence and power of the central authority of the state. Allen's association with G. D. H. Cole went back to pre-war days, when they were both involved in efforts to shake up the Fabian Society, but at this time Cole was not calling himself a guild socialist. ${ }^{5}$ From December 1914 on Allen was preoccupied with running the No-Conscription Fellowship, and from mid-1916 on he was in and out of prison for objecting to any kind of service which would assist the war. His ill-health meant that imprisonment was followed by periods, all too brief, of convalescence, during the last of which he spent much time reading the literature of guild socialism, ${ }^{6}$ which by this time was fully fledged.

1 See R. E. Dowse, Left in the Centre (London, 1966), ch. 2; and Marvin Swartz, The Union of Democratic Control in British Politics during the First World War (Oxford, 1971).

Dowse, op. cit., p. 27.

3 See A. Marwick, Clifford Allen (Edinburgh, 1964), p. 30.

4 Dowse, ibid.

s Margaret Cole, The Iife of G. D. H. Cole (London, 1971), p. 74.

- Marwick, op. cit., pp. 46-48. 
Allen responded enthusiastically to this literature. In January 1918 he commented: "The more I read and think about this new way of getting all the good things of socialism with a minimum of interference by a bureaucratic state, the keener I become about it." 1 Early in 1919 he joined the executive of the National Guilds League, ${ }^{2}$ and became convinced that the ILP must recover its pre-war role of "pioneering Socialist thought and action" 3 within the labour movement by adopting a programme which distinguished it from the Labour Party, and was more advanced than Labour and the New Social Order - otherwise the party would become redundant. His view, naturally enough, was that the ILP should adopt a guild-socialist programme.

The 1920 conference of the party saw the passage of a motion calling for "an effective political and industrial organisation of the workers, whether by hand or by brain", which clearly differentiated between

"the Capitalist collectivism implied in the nationalisation of essential services, controlled by a bureaucratic Central Government, and the social control in the interests of the whole community, implied by joint control by representatives of the general community and the workers in particular industries". 4

Allen evidently had much support for his position, and he was instrumental in securing the setting up of a committee to consider, among other matters, "what fresh proposals require to be formulated in the Program of the Party". 5

The committee's discussions and conclusions were reported to the 1921 conference of the party. All members who participated were united in the view that the object of the ILP as a socialist organisation must be "to end the present Capitalist System and its exploitation of Labour, together with all forms of hereditary and economic privilege, and to establish a system by which the community will own, organise

1 Diary, 29 January 1918, Allen Papers, quoted in Marwick, op. cit., p. 48.

2 Marwick, op. cit., p. 52; Cole, op. cit., p. 124.

${ }^{3}$ Letter in Labour Leader, 12 February 1920, quoted in Dowse, op. cit., p. 66.

4 ILP, Conference Report 1920, p. 61.

5 ILP, Conference Report 1921, p. 13. The committee's membership was: Ramsay MacDonald, Clifford Allen, Norman Angell, Margaret Bondfield, H. N. Brailsford, Fred Bramley, G. D. H. Cole, Mary Agnes Hamilton, Frank Hodges, Fred Jowett, B. N. Langdon-Davies, Neil Maclean, J. S. Middleton, Tom Myers, C. H. Norman, Philip Snowden, R. C. Wallhead, Leonard Woolf, E. Shinwell, and David Kirkwood, with Emile Burns as secretary. Of these, Allen was prevented by illness from taking any part in the work of the committee, and Margaret Bondfield, Brailsford, Hodges, and Myers for various reasons also took no part. MacDonald, though chairman, felt unable to sign any of the subsequent reports of the committee. Ibid., p. 66. 
and control its resources for the benefit of all". It was united also in its proposals for the control and management of communal property.

"The amount and character of communal production and service, the determination of the principles governing the division of the national income, and the co-ordination of supply and demand, must be in the hands of a central body and local bodies representative of the people both as producers and consumers.

The internal management of each industry must be in the hands of the workers - administrative, manual, and technical engaged therein, operating in conjunction with representatives of the organised consumers." 1

The committee recognised that this involved a definite change from traditional theories of state socialism, but argued that workers' control was "the only way to avoid bureaucracy after the socialisation of industry". The role of Parliament - the political sphere - would be diminished: "all responsibility for the industrial organisation of society" would be placed in separate bodies, "representative of the organised producers and consumers", at both central and local levels. There were arguments that such arrangements would be more efficient, but of greater importance was the central moral proposition of guild socialism: "such a system is valuable because it gives the producers, through their own organisations, a definite place in the constitution, and a responsibility which they have the right and the duty to assume."2 There was some difference of opinion as to how far it was possible to be specific about the constitution and sphere of competence of the central bodies, both industrial and non-industrial, and in particular about how far any co-ordinating institution, jointly representative of these bodies, "should be purely advisory, or should be the ultimate authority over both of the constituent bodies". ${ }^{3}$ The issue was left undecided.

There were differences of emphasis among members of the committee on the immediate objects of the party, one group, including Cole, Kirkwood, Langdon-Davies, Maclean, Norman, Shinwell and Woolf, stressing the achievement of working-class control over industry, and the remainder stressing the capture of local and national governing bodies, but each group accepted the validity of the other's aims. ${ }^{4}$ There was again a separation of views about the methods to be used in achieving these objects. Cole, Langdon-Davies, Norman and

1 Ibid., p. 71.

2 Ibid., p. 67.

3 Ibid., p. 69.

4 Ibid., p. 73. 
Woolf argued that "the existing Parliamentary system is inconsistent with real democracy $[\ldots]$; that real democracy is impossible while economic power remains in the hands of a privileged minority", and that "the organised workers may be driven to secure the aims set forth in this program by extra-constitutional means such as direct action or revolution". The remainder of the committee argued that, as "elections under the existing British Parliamentary system frequently result in false and inadequate representation, $[\ldots]$ it may be necessary on specific occasions for the organised workers to use extra-political means, such as direct action". The entire committee agreed that "the best means of effecting a peaceful revolution is for the organised workers to prepare themselves to take over the industrial machine". 1

The committee was thus divided, but the divisions were by no means clear-cut. Where conflicts did exist, of the fourteen members whose signatures appeared, Cole, Langdon-Davies, Norman and Woolf were always to be found signing together on one side, as were Bramley, Snowden and Wallhead, on the other. There were therefore seven other members of the committee, or half its active membership, who clearly thought they belonged to neither group exclusively. In view of this, it is difficult to accept R. E. Dowse's conclusion that "in this report the division between the politicians and the guild socialists is obvious and complete". 2 Dowse continues, with quotations from the report, as follows:

"Section 6, 'Immediate Objects', exemplifies the difference well. For the politician the objects were 'to capture local and national governing bodies, and to assist in extending the activities of local authorities on Socialist lines'. For the guild socialists, they were 'the co-ordination and development of T.U. organisations with a view to the securing of full working class solidarity and the obtaining of control over industry'. Equally clearly the difference comes out in Section 8, on 'Method', where the politicians stressed votes and parliamentary government, whilst the guild socialists claimed 'that the change to socialism can only be effected by the action of the organised worker ... holding that the best method of effecting a peaceful revolution is for the organised workers to prepare themselves for a taking over of the industrial machine'."3

Dowse, in fact, has based his conclusions on misleading quotations. The full text of the alternatives contained under Section 6 is as follows:

1 Ibid., p. 74.

2 Dowse, op. cit., p. 67.

${ }^{3}$ Ibid., pp. 67-68. 


\section{Immediate Objects.}

The I.L.P. recognises that, with a view to the application of Socialist theories when political and economic power has been attained, the first tasks of the Socialist movement are

(a) to capture the local and national governing bodies, and to assist in extending the activities of the local authorities on Socialist lines;

(b) to strengthen and expand the Co-operative movement, with a view to representing the domestic consumers in the future Socialist Commonwealth;

(c) to stimulate the workers' organisations in the direction of the control of industry.

Norman Angell, F. Bramley, Mary Agnes Hamilton, F. W. Jowett, J. S. Middleton, Philip Snowden, R. C. Wallhead.

\section{Immediate Objects.}

The I.L.P. recognises that, with a view to the application of Socialist principles when the working class has attained to power, the first tasks of the Socialist movement are

(a) the co-ordination and development of Trade Union organisation with a view to the securing of full working-class solidarity, and the obtaining of control over industry;

(b) the strengthening and expansion of the Co-operative movement, with a view to making it the effective representative of the domestic consumer in the future Socialist Commonwealth;

(c) the capture of local and national governing bodies, with a view to the development of administration on Socialist lines and the destruction of the machinery of the capitalist State.

G. D. H. Cole, David Kirkwood, B. N. Langdon-Davies, N. Maclean, M.P., C. H. Norman, E. Shinwell, Leonard Woolf. ${ }^{1}$

On Section 8, Dowse has simply misquoted. The "politicians" did not stress "votes and parliamentary government", and all members held to the views expressed about the best means of effecting peaceful revolution, though Cole, Langdon-Davies, Norman and Woolf did argue that only "the action of the organised workers" could effect "the change to Socialism"2 - there was no role for Parliament consistent with "real democracy". If the division had been as obvious and complete as Dowse suggests, then it would be difficult to account for the acceptance by the ILP a year later, in 1922, of a guild-socialist constitution, without, at the same time, pointing to a split in the

1 ILP, Conference Report 1921, p. 73.

2 Ibid., p. 74. 
party which did not occur. The differences in opinion over the party programme were sufficient, however, for the National Administrative Council to accept, and the conference to endorse, its reference back for further consideration. ${ }^{1}$

The constitution adopted by the ILP at its 1922 conference was based on the agreed portions of the report of the policy committee.

"The Independent Labour Party believes in democracy organised both in its political and industrial aspects, for communal ends.

The basis of political democracy must be the whole body of citizens, exercising authority through a national representative assembly, directly elected by the people, with a decentralised and extended system of local government.

The basis of industrial democracy must be: (1) the organisation of the wage and salary earners; and (2) the organisation of consumers." 2

Were it not for a resolution moved by C. R. Attlee and then carried, the form of the machinery for co-operation between producers and consumers would have been left indefinite, to be determined at a later date. But Attlee argued that belief in workers' control should not blind people to the need for a central authority. "They must not have a number of industrial republics fighting each other". ${ }^{3}$ Attlee's resolution, which was embodied in the new constitution, was:

"A central body, representative of the people both as producers and consumers, must decide the amount and character of communal production and service necessary. The internal management of each industry must be in the hands of the workers, administrative, technical and manual, engaged therein, operating in conjunction with the representatives of organised consumers. Experience will determine the methods of co-operation and the detailed form of organisation, as step by step is taken towards the attainment of the Socialist Commonwealth."4

While the need for a central co-ordinating body was thus recognised, it was still left indeterminate whether this body was to be purely advisory, or whether it would possess full legislative authority over all industry. Ramsay MacDonald understood that its function would be advisory: he accepted Attlee's resolution on the understanding that

1 Ibid., p. 138.

2 ILP, Conference Report 1922, p. 92.

3 Ibid., pp. 68-69; for Attlee's guild socialism see W. Golant, "The Early Political Thought of C. R. Attlee”, in : Political Quarterly, XL (1969).

ILP, Conference Report 1922, p. 92. 
the central body would only be "an administrative body within the political State". 1 The constitution re-iterated the broad agreement of the report of the policy committee that "the best way of effecting a peaceful change to Socialism is by the organisation of the workers politically to capture the power of the State, and industrially to take over the control and management of the industrial machine"."

Dowse's comment on the new constitution was that "although the policy was adopted, neither Snowden nor MacDonald ever accepted it". 3 If the implied question to which Dowse's words are a comment rather than an answer is: did Snowden or MacDonald seek to follow ILP policy when they were in office? - then the answer is: no! But there was nothing in the constitution which Snowden could have disagreed with in the light of his response to the report of the policy committee. Again, though MacDonald refused to sign any sections of this report, even he thought sufficiently seriously about the new constitution to interject his own remarks about the nature of the central co-ordinating body. It may be that the prospect of office, certainly for Snowden, ${ }^{4}$ rather less so for MacDonald, had much more to do with their later changes of view than any intellectual or moral antipathy to ideas of guild socialism. At the time in question, April 1922, office, though in fact only twenty months distant, was much further distant in even the most percipient of minds. Indeed the debate in 1921 and 1922 was not about guild socialism at all, since all signatories to the policy committee's report were agreed on its appropriateness, but about other matters such as the propriety or not of extra-constitutional action, the precise powers to be given to the central coordinating authority, and whether greater emphasis should be placed on industrial as opposed to political action.

Despite these developments in ILP policy, perhaps because of them, we are not very near a concept of planning. The next stage in the development of the party's policy filled this gap. It was at this same 1922 conference of the party that Clifford Allen was elected treasurer, and began to exert his maximum influence on the party not only in the matter of securing its finances, but in that of the programme of the party. His influence increased when he was elected chairman of the party at the following conference, a position he held until tension between himself and James Maxton on the way the party should be led, erupted to the point of provoking his resignation during the annual conference of the Labour Party in October 1925.

1 Ibid., p. 68.

${ }^{3}$ Dowse, op. cit., p. 69.

2 Ibid., p. 93.

- See Colin Cross, Philip Snowden (London, 1966), pp. 174-75. 
Allen had been prevented from taking part in the discussions of the policy committee during 1920-21 because of illness - illness contracted in Russia. He had gone to Russia in the summer of 1920 with R. C. Wallhead, chairman of the ILP in 1921, with the purpose of discovering in what form the Third International was to be constituted and whether the ILP should join it. They accompanied an official delegation of the TUC and the Labour Party occasioned by a resolution passed at a special TUC conference on 10 December 1919. The resolution demanded "the right to an independent and impartial inquiry into the industrial, political and economic conditions in Russia". ${ }^{1}$ In the report of the official delegation, which was "submitted to and also endorsed by" Allen and Wallhead, was a fairly lengthy reference to the production of the country "being dealt with according to an 'Economic Plan' largely under the direction of the Supreme Council of National Economy". There followed a description of the institutional arrangements for giving effect to this plan, together with an account of the practical difficulties that were being encountered, principal among which were "the restrictions on external trade, and $[\ldots]$ the Polish offensive". It was explained to the delegation that

"The economic plan contemplates 50 productive departments, a financial department, and a department to co-ordinate the work of local economic councils which exist in different towns, in the different governments and in larger areas (oblasts) embracing more than one government. Each department is controlled by a director or a Collegium of three or five members, and the whole of the Supreme Council is controlled by a Praesidium of eleven members nominated by the Central Executive Committee of the Trade Unions, and confirmed by the Council of People's Commissars.

The functions of the Supreme Economic Council are: - (1) Industry; (2) the financing of Industry and the parcelling of raw materials. There are 5,000 nationalised enterprises, of which 2,500 are grouped into 179 trusts and directed by the Council itself; $70 \%$ of these enterprises are working. 2,500 enterprises are managed by local Economic Councils forming part of the Provincial (Gubernia) organisation, but directly responsible to the Supreme Economic Council. The Supreme Economic Council has the power of veto over the members proposed for appointment to the local Economic Councils. Food, fuel, raw material of industry and transport, and material for education are all supplied

1 Trades Union Congress and The Labour Party, Report of British Labour Delegation to Russia, 1920 (London, 1920), p. 5. 
by the Supreme Council of National Economy. In the case of bread, for instance, a special commission representing the Food Commissariat, the Central Executive Committee of the Soviets and the Supreme Economic Council fixes the amounts of food for different categories of workers, and then distributes the bread available according to the reported population of each district. The work of the Council is thus highly centralised; and M. Milutin [assistant to the Commissar of the Council] explained that in connection with the nationalisation of industry "the main line of policy is to establish centralised organisations."

Allen did not refer to these aspects of Russian economic affairs in his own report to the ILP, though he did set down some private comments in which he was highly critical of the centralist features of the Russian experiment, however necessary they might be, given the stage of development of communism in Russia. ${ }^{2}$ Fenner Brockway noted a more positive response which was to anticipate much of Allen's thinking from 1923 on, though there is little clue, ${ }^{3}$ apart from Brockway's account, that in the summer of 1920 Allen directly related Russian experience to current British politics. Brockway, recalling a "scrap of conversation I had with him on his return from Russia", suggested that Allen likened the task of the socialist to that of the doctor.

"The body politic is suffering from ills: what is their cause, what is the remedy? Both the diagnosis and the treatment must be made with exactness. [...] If a doctor were called in to deal with a critical case, would he apply less than the remedy required because those who summoned him to the patient's bedside were ignorant of medical science? If he did he would be unworthy of his calling and a traitor to truth. The same with the Socialist. Given an opportunity to remove the ills of society he must seize it boldly, winning public opinion by the success of his operation."4

From 1923 on there was a marked shift of emphasis in ILP literature away from the categories of the discussions which had preceded the adoption of the 1922 constitution. Guild-socialist ideas still retained a place, but greater attention was paid to more immediate measures for dealing with unemployment, which was beginning to be regarded as

1 Ibid., pp. 14-15.

2 Allen Papers, quoted in Marwick, op. cit., pp. 62-64.

${ }^{3}$ There is no clue, for instance, in Martin Gilbert, Plough My Own Furrow (London, 1965), p. 166, where part of Brockway's account is reproduced.

4 Fenner Brockway, Inside the Left (London, 1947), pp. 143-44. 
chronic. It was no longer possible, as it had been during the two or three years after the war, to explain unemployment away by reference to the disturbed and chaotic economic conditions prevailing in Europe. Capitalism itself was to blame. In November 1923 the ILP published a summary of its constructive proposals, The Socialist Programme, which was signed by Clifford Allen, Fenner Brockway and Ernest Hunter.

"Capitalism does not attempt to organise labour to meet human needs. Each Capitalist concern works separately for its own profit. There is no broad scientific survey of the materials and productive capacity available in relation to the requirements of the community. As a consequence trade booms and prosperity are followed by glutted markets and privation."1

In the remainder of The Socialist Programme elements of the economic thought of J. A. Hobson, J. M. Keynes and E. M. H. Lloyd are all contained. ${ }^{2}$ One of the initial points, indeed the ILP's "first object", was pure Hobson: "to secure a more equal distribution of wealth so that the demand for goods would be increased and stabilised."3 A living wage would be enforced on every industry; old-age, sickness and unemployment allowances would be introduced coupled with the taxation of "luxury incomes"; and the land and capital owning classes

1 Clifford Allen et al., The Socialist Programme (London, 1923), p. 9.

2 The ILP was to make much use of J. A. Hobson's underconsumptionist argument, and Hobson indeed was one of the signatories of The Living Wage, much to Beatrice Webb's offended surprise (Diaries 1924-1932, ed. by Margaret Cole (London, 1956), p. 89, entry of 16 April 1926). The emphasis of Keynes and Lloyd on the stabilisation of internal prices, at the expense, if necessary of the external exchange rate, is also to be found. Whereas Keynes argued for government management of economic aggregates to achieve this end, Lloyd pointed to the necessity of taking social purposes into account, for which a more interventionist role on the part of government was required, especially in the allocation of funds for investment. Lloyd also emphasised the importance, for the object of internal price stabilisation, of international control of the supply and prices of foods and raw materials entering into foreign trade. See J. A. Hobson, The Economics of Unemployment (London, 1922); J. M. Keynes, A Tract on Monetary Reform (London, 1971; first ed. 1923); E. M. H. Lloyd, Stabilisation (London, 1923). Though Keynes's Tract was not published until December 1923, a month after The Socialist Programme, the articles on which it was based had appeared in the Manchester Guardian the year before. For a fuller consideration of the relevance of Hobson, Keynes and Lloyd to the development of the economic policy in the ILP and the Labour Party, see A. Oldfield, "The growth of the concept of economic planning in the doctrine of the British Labour Party, 1914-1935" (Ph.D. thesis, University of Sheffield, 1973), pp. 132-52.

3 The Socialist Programme, p. 10. 
would be eliminated. In the next passage arguments reminiscent of Lloyd and Keynes are used to reinforce the aim of stabilisation:

"Socialists would advocate the setting up of a Committee on Production with powers to institute a complete national stocktaking. They would consider the needs of the nation, and the labour and agricultural and industrial resources available to meet them. They would control the purchase and distribution of raw materials. They would expedite or relax Government orders so as to regulate the demand for labour. [...] The bank plays a large part in the causation of trade booms and depressions. Socialists would scientifically control credit in the public interest. For instance, during a time of depression the bank-rate might be steadily reduced until industry expanded. This would be the first step in the socialisation of credit."1

The dual purpose of controlling banking and credit was emphasised in a later passage: the actions of banks did have an effect on levels of employment (the government-initiated deflationary policy was quite palpably affecting employment levels at that time), and did further influence, if not control, the amount and type of investment spending. Monetary policy was at least as important as production policy Keynes and Hobson were fused.

"Unemployment is largely due to lack of purchasing power caused by a contraction of bank loans. One vitally important remedy for unemployment is therefore an expansion of purchasing power brought about by an increase of bank advances. But this can only be done safely and effectively by appropriate action on the part of the Government and the Bank of England. In other words, it rests with the Government and the Bank of England to determine whether unemployment shall continue or not. General unemployment has nothing to do with tariffs or free trade. It is determined by the monetary policy pursued by a country and not by its tariff policy. ${ }^{2}$

[...]

Unemployment can be cured; this must involve State regulation of banking and credit.

Apart from its effect upon this problem of unemployment Socialists propose that the State should control banking because that would give the Government a determining voice in saying

1 Ibid., pp. 10-11.

2 The Socialist Programme appeared at the time when Baldwin had called a general election over tariff reform. 
when and how particular industries should be encouraged or discouraged. To control the speed and direction of credit in a world of luxury and necessity trades is of the greatest importance if we are to commence to run industry according to a common plan with a definitely thought-out design."1

Science was waiting to be applied to industry. To adopt a "common plan" was to act scientifically. Stressing the necessity for unity of purpose, The Socialist Programme argued:

"The whole industrial field must be viewed as a general considers and plans his campaign. Could a battle be won if each battalion fought separately for its own gain? Can a nation's industry prosper if each trade or combine works alone and for its separate profit? Few soldiers would give their lives for the private profit of their commanders. Few workers will bend their energy for the private profit of their employer."2

The themes of science and war appeared in the ILP's election manifesto of 1923, which concluded this particular section with the question: "Can the method of science be applied to nothing save the organisation of men for war and their equipment with instruments of destruction?"3 Clifford Allen wrote similarly in an extended version of his presidential address to the ILP annual conference in spring 1924:

"What we need is a new morality which seeks to apply men's endurance, loving kindness, and capacity for sacrifice and heroism, to carry into effect scientific remedies for ascertained ills. To think scientifically, and act accordingly is the true morality of the future.

[...]

We all know that this chaos and suffering cannot be remedied unless we organise our national resources by means of disinterested scientific methods.

$[\ldots]$

All observers recognise that disorder and absence of national planning are behind the industrial chaos of the last few months."4

The concept of planning was inextricably linked with that of science. Circumstances were observed in the light of socialist principles, and this process revealed the kind of problems which needed attention.

1 The Socialist Programme, pp. 26-28.

2 Ibid., pp. 22-23.

3 Reproduced in The Times, 20 November 1923.

4 Clifford Allen, Putting Socialism into Practice (London, 1924), pp. 23, 26-27. 
Planning, the disinterested and dispassionate application of science, the development of "scientific well-thought-out stages", 1 would provide solutions to economic and industrial problems. Institutionally there would be a Committee on Production to decide on the allocation of resources, especially raw materials, within industry, and from the point of view of investment spending, this task would be done by a revivified Treasury and Bank of England, invested themselves with new purposes by a socialist government. There is an unresolved division of authority here, for clearly much investment spending, the responsibility of the Treasury and the Bank of England, would be on raw materials, whose allocation was the responsibility of the Committee on Production. The scales, though, would seem to be weighted in favour of the Treasury and the Bank of England, in view of their control of short-term credit in addition to investment spending.

The central concern of The Socialist Programme was with unemployment, and the ideal of citizenship contained in the party's 1922 constitution was overlaid. It still had a place: "Nationalisation, under a Socialist Government, [...] would mean public ownership with workers' control in its widest sense - administrative, technical, and operative". ${ }^{2}$ Only by the transformation of industry "from an organisation conducted for private gain into a great self-governing public service"3 could one expect workers to contribute in a spirit of common service. There is an undoubted shift of emphasis here. Workers' control is now a second- and not a first-order principle.

"Nationalisation is now demanded because industrial progress is being hampered by the haphazard wasteful method under which industry is being conducted. Industry is now victim of chance: it is conducted without a common plan."

The purpose of nationalisation was only secondarily to provide opportunities for workers' control; it was primarily advocated to rescue industry: to prevent "the scramble for private profit" from leading to "the wasteful squandering of the world's natural resources, to over-production one moment, to under-production the next". 4

Much of the ILP literature, and Allen's writing in particular, in late 1923 and early 1924, was developed in response to first the prospect, and then the actuality, of Labour government. Allen's point was that a bold advance towards socialism should be made whether the government was in minority or not, and that refusal of a Parliamentary

1 The Socialist Programme, p. 24.

2 Ibid., p. 22.

3 Ibid., p. 24.

1 Ibid., pp. 22-23. 
majority should be followed by a general election in which such a bold advance would be the major issue: let the electorate then decide with a clear exposition of the alternatives before it. ${ }^{1}$ This was not Ramsay MacDonald's way, however: the limits of the possible had, perforce, to be much less adventurously defined. ${ }^{2}$ Writing before his installation as Prime Minister, he offered his own conception of gradualness:

"We shall take society as a going concern and keep it going while it is being transformed. Working under conditions of representative democracy, we could move only step by step, subject to being challenged at every step and post. At most, a Government lasts for five years. Therefore, Socialism, like Christianity, or Individualism, can never become a true political issue."

The constructive reaction of the ILP to such posturings was to appoint a series of Inquiry Commissions, of which the most important was that on the living wage. This commission was composed of Frank Wise, H. N. Brailsford, Arthur Creech Jones, with J. A. Hobson as chairman. It began work shortly after the 1925 conference, ${ }^{4}$ and produced an interim report for discussion at the Easter conference of the ILP in 1926. This was Socialism In Our Time. Before considering this, however, we must examine the antecedents of the demand for a living wage.

\section{THE SOCIALISATION OF INCOMES}

Two arguments were generally put forward in favour of some form of minimum or living wage: a humanitarian argument, that it was an affront to the dignity of man that he was often forced to exist on an income which could not guarantee him a minimum standard of civilised life; and the underconsumptionist argument, that trade depressions and unemployment were the result of a disproportionate share of the national income going to the already wealthy classes - the provision of a minimum or living wage would so redistribute the national wealth that such depressions and the unemployment they

' For an elaboration of Allen's views see Marwick, op. cit., ch. X; and Dowse, op. cit., ch. 9.

2 For a consideration of Ramsay MacDonald's approach see Leo V. Panitch, "Ideology and Integration: The Case of the British Labour Party", in: Political Studies, XIX (1971), p. 190; and C. L. Mowat, "Ramsay MacDonald and the Labour Party", in: Essays in Labour History 1886-1923, ed. by Asa Briggs and John Saville (London, 1971), pp. 148-49.

3 J. R. MacDonald, Why Socialism Must Come (London, 1924), p. 10.

- ILP, Conference Report 1926, p. 9. 
entailed would be avoided. The demand for a living wage was eventually to develop into one for the socialisation of credit, and ultimately the nationalisation of banking and the public control of investment.

Fred Jowett exemplified the humanitarian approach. He had gone to Geneva in the summer of 1920 to attend, in company with Ramsay MacDonald and others, an international socialist conference to discuss war guilt and the peace treaties, and also the question of devising a blueprint for socialism. ${ }^{1}$ He served on a commission of the conference dealing with socialisation; its preoccupations frustrated him. To argue about elaborate proposals for nationalisation, "the kind of machinery of government by which Socialism should be administered, the nice balancing of geographical and vocational representation, or of both combined", was to miss unforgivably an opportunity for doing something immediate to relieve poverty and unemployment by shaking off "the whole horde of parasites who live on rent, interest and profit". "Let us boldly demand," he wrote in an article on his return, "here and now, that the right to consume commodities, howsoever produced [...] should be based on service." 2 Nationalisation could only proceed slowly, and in their early stages the industries nationalised would have to bear the cost of compensation to former owners. The first call on socialists, therefore, was to improve the conditions of life of the mass by the socialisation of incomes. Much could be done under this head immediately - by redistributing the national income such as to provide a living income, and allowances and social services for the young, the old and the sick - without waiting until the whole of industry was nationalised. While the humanity of his appeals may have been respected, Jowett failed, at this stage, to gain the commitments from the ILP that he wanted.

The humanitarian argument for a minimum or living wage had always had a place in ILP literature, but it was not until it was fully under-pinned by the underconsumptionist argument that the idea made much official headway in the ILP. It was Clifford Allen, more than anyone, who was responsible for indicating the possibility of juncture, and $\mathrm{H}$. N. Brailsford who effected it.

Allen, in his presidential address to the 1924 party conference, recommended the setting up of a "permanent national commission, composed of all the interests concerned [...] to anticipate and watch over all wage problems and to safeguard the proper use and coordination of all our national resources". Its first job could be to "recommend the adoption of the principle of the national minimum wage varying

1 See Fenner Brockway, Socialism Over Sixty Years (London, 1946), pp. 176-82.

' Bradford Pioneer, 31 December 1920, quoted in Brockway, op. cit., p. 180. 
in its application from industry to industry". In this way the "chaotic pressure of strikes and lock-outs" could be avoided. ${ }^{1}$ At the following year's conference he called for "Labour to make a united demand for a universal minimum wage", the minimum to be "dictated by the needs of a civilised existence". The demand was to set in train a whole process of socialisation of economic activity. Once the level of the wage had been fixed, then each industry could be turned to

"with the demand for such re-organisation as will enable that wage to be paid. As each industry fails to fulfil that condition, the grip of society will tighten upon it and the inevitable transfer to national ownership and scientific organisation will follow.

[...] The more the nation becomes responsible for the control of its staple industries, the more vital it will be that national resources shall be used to the greatest advantage, and the purchasing power of the consumer be enhanced by the re-direction of production. In other words the banking system will have to be transferred to the hands of the community."

Further, and to eliminate the profiteering of the middleman, it would be necessary to control the import of food and raw materials. Each nation, in properly and scientifically satisfying human needs, would "in the end have to join in the organisation of world trade". ${ }^{2}$ All measures of socialisation therefore could be predicated on the basis of a demand for a living wage.

Six months after this 1925 conference Allen resigned leadership of the ILP, but not before the conference had appointed its Living Wage Commission. The reports of this commission, Socialism In Our Time and The Living Wage, were largely the work of $\mathrm{H}$. N. Brailsford, its secretary, who had been writing a series of articles during the early months of 1925 in the New Leader, of which he was editor. The articles expounded the kind of socialism he thought appropriate for the time, and they were gathered together, expanded and published in October 1925 in a volume called Socialism for To-Day. Brailsford did not use the terminology of planning in this book, but it will be argued nevertheless that he did make the connexion between the underconsumptionist argument for the expansion of credit, and the need for a planned economy with public control of banking occupying the critical position. This was to be the kernel of the recommendations of the final report of the ILP's Living Wage Commission.

Brailsford had argued, when it was still in question whether the

1 Clifford Allen, Putting Socialism into Practice, pp. 20-21.

2 ILP, Conference Report 1925, pp. 92-93. 
Labour Party would take office after the 1923 general election, in tune with Allen about how office should be used: "If we take office we must be ready to live dangerously." 1 The experience of office concerning the relief of unemployment and poverty was disappointing and potentially disastrous, for failure to deal with the misery and desperation they caused fostered "the temper which makes revolutions". Any future Labour government, even if it was in minority, must therefore "prepare itself for an effort revolutionary in extent if not in method". He argued forcefully against adopting "the watchword of evolution", for this was tantamount to renouncing the "aim of bringing about the fundamental change in the basis of society and industry. A party which rejects revolution, and imagines that it has endless time in which to achieve its end, may soon cease to work for it at all."2 Bold and comprehensive measures were required. Problems could not be tackled in isolation: the existing system in its entirety must be challenged. In one short sentence Brailsford indicated what he meant. "One could not [...] impose on industry the obligation to pay a true living wage, without at the same time facing the regulation of credit, the control of prices through the importation, by a National Board, of food and raw materials, and the reorganisation of the more depressed industries."3

In Socialism for To-Day Brailsford acknowledged many debts, both "constructive" and "critical", to among others E. M. H. Lloyd's Stabilisation, to the Webbs, J. A. Hobson, E. F. Wise, Clifford Allen, and later in the book, in its crucial chapter "The Tactics of Transition", more specifically to Lloyd and also to Keynes's $A$ Tract on Monetary Reform. ${ }^{4}$ Brailsford accepted the Hobsonian analysis that unemployment was a recurrent evil of the modern capitalist industrial system, for under this system the distribution of income favoured too much those who saved a large proportion of their income. The masses lacked "what economists call an "effective demand"." "In plain words", he continued, "they cannot buy what with ease might be produced." 5 Brailsford's position, however, was that the underconsumptionist argument was an inadequate explanation of Britain's unemployment problems in the post-war period, for these were largely the result of the deflationary credit policy pursued by the Bank of England in relation to the restoration of the gold standard at the pre-war parity. This "deliberate act of policy, a decision taken by a few bankers

1 New Leader, 16 December 1923, quoted in Marwick, op. cit., p. 85.

${ }^{2}$ H. N. Brailsford, Socialism for To-Day (London, 1925), pp. 68-69.

3 Ibid., p. 69

Ibid., pp. 5, 120-21.

Ibid., p. 38. 
responsible only to their shareholders" was more than anything else responsible for the persistence of a level of unemployment which under normal conditions would at least have been partially alleviated by the activity of the trade cycle. The masses of the country were prisoners of an élite in whose hands economic power was concentrated. This was the "central evil", and the "main purpose of Socialism must be the conquest for the whole community of economic power". ${ }^{1}$

"The dictatorship of the capitalists, each pursuing his own private gain", plainly did not, "without planning or purpose, work out for the common good." A fundamental characteristic of socialism, Brailsford stated, was the "belief that reason and science can organise and co-ordinate our efforts more successfully than the haphazard play of competing needs and greeds". ${ }^{3}$ This belief led to demands for the collective control of the means of production, but Brailsford wished to reverse the traditional order of socialist thought. "Hitherto", he pointed out, "Socialists have argued in their propaganda that if industry and the land were nationalised, the consequence would be an increase in our national wealth, and a fairer distribution of the national income." The defect of this line of reasoning was that to the average man it seemed rather remote in its benefits. What was necessary was a measure which would immediately raise the standard of life, and which would lead, if applied comprehensively, inevitably to other changes demanded by more traditional socialist orhodoxy. This measure was the living wage. Brailsford began by demanding a redistribution of income. "Let us insist, first of all, on the elementary human claim to a living wage, and then enforce the wider economic changes by which alone it can be realised and secured." 4 While in this passage Brailsford clearly did not demand a living wage in order to stimulate production and hence employment, but because such a demand was an "elementary human claim", the earlier passage quoted, that production and therefore employment were lower than they need have been because of a lack of "effective demand", indicates his acceptance of the underconsumptionist position. In truth the two arguments are complementary, and each is invoked when it seems appropriate. Brailsford wished to avoid inflation, however, and in this connexion he recognised that any rise in the general level of money wages was potentially inflationary, for "a general rise in real wages can be secured only if we can stabilise the general level of prices". ${ }^{5}$

In relation to this aim there were three lines of attack which needed pursuing simultaneously: action to control the price and availability

1 Ibid., pp. 34-36.

3 Ibid., p. 95.

2 Ibid., p. 14.

5 Ibid., emphasis added.

4 Ibid., p. 119. 
of credit through the socialisation of banking; the nationalisation of the railways, electricity supply and the coal mines to control, and more particularly to keep low, the prices of transport and power; and the control of the prices of raw materials which, since Britain depended on foreign sources of supply, entailed the central control of imports. In order also to protect the cost of living, and the income of farmers, Brailsford advocated control of the imports and prices of foodstuffs, especially those items which were also produced domestically.

In stating his position on the control of credit, Brailsford referred explicitly to E. M. H. Lloyd and J. M. Keynes for support of his analysis that the banker is "the autocrat who regulates the trade cycle, and in so doing controls the lives and homes of working men and women more effectively than any Parliament". Both Lloyd and Keynes had shown that "a scientific credit policy can, with adequate organisation, prevent any considerable fluctuation" in the general price level, by restricting the availability of credit in conditions of potential boom, and doing the reverse in opposite conditions. Such a policy would maintain employment constant and steady, and "would give to industry a confidence which it has never enjoyed since the industrial age began". ${ }^{\text {This }}$ was not quite Keynes's point, but Brailsford accepted Keynes's argument that unpredictable fluctuations in prices increased the risk attaching to the manufacturer's investment decisions, and that with price stability the energies of the manufacturer would be free "for his proper work of perfecting his technical processes". 2

It was insufficient, however, to induce or compel bankers so to regulate credit as to keep the general price level stable, for this would still leave the bankers free to decide the purposes to which the credit could be applied. "If one builder requires credit for a cinema, and another for cottages, the two demands are weighed against each other on business grounds alone." The banks would have to be nationalised in order that "social policy can be brought in to guide the stream of credit". ${ }^{3}$ This was to go somewhat further in the direction of explicit planning than either Lloyd or Keynes thought desirable, but little progress could be made "towards the scientific organisation of industry until we have socialised banking, and given the banker an honourable place as the expert who carries out a national credit policy".4

Power over industry as a whole, to direct the development and control the prices of particular industries, required two further

1 Ibid., pp. 96-98.

2 Ibid., p. 98; see Keynes, op. cit., pp. 32-34.

Brailsford, op. cit., p. 99 Ibid., p. 97. 
measures. Transport and power entered into the cost of all goods produced: they were commanding industries, and it would be folly to delay one day in taking them over. ${ }^{1}$ The other measure was the control of raw materials. Brailsford's recommendations here were almost directly taken from Lloyd. It was necessary to control their prices for reasons of price stabilisation, and the war had shown that this could be done "with conspicuous success and at a handsome profit".

"The aim and technique would be broadly the same - to economise by concentrating the nation's buying under a central direction; to keep prices steady, by purchase in bulk on long-term contracts, with a reserve to cover the uncertainty of supply and demand; to abolish speculation, and to stop the diversion of wealth into the hands of traders who thrive on scarcity."2

The problem of stabilising prices by controlling credit and raw materials would be made much easier, Brailsford admitted, if, on the one hand, the central banks of all countries recognised the League of Nations as the international monetary authority, and, on the other, international commissions were created similar to those which had been in operation in wartime for regulating the supply, demand, and price of raw materials. ${ }^{3}$ In these respects, Brailsford merely echoed the substance of arguments put forward by Keynes and Lloyd.

There is little in Socialism for To-Day on the institutional aspects of planning - the state is the most frequent institution referred to; especially absent is any detailed consideration of the mechanisms of overall central control and co-ordination, save that this would be an area in which the Bank of England would be heavily involved. There is little talk either about planning as a concept. It is safest, if unimaginative, to conclude that the term had not entered Brailsford's consciousness as one laden with the kind of meaning and importance which was attached to it in The Living Wage. It is nevertheless clear that Brailsford was writing about the planning of economic and industrial activity for social purposes. Essentially Socialism for To-Day represented the kind of ideas and analysis which Brailsford took with him into the deliberations of the ILP's Living Wage Commission. Given the injunction on industry to pay a living wage, a corpus of further changes could be predicated which included the major component of a system of planning - the control of banking and credit. Socialism for To-Day appeared in October 1925, by which time the

1 Ibid., pp. 103-04.

2 Ibid., pp. 100-01.

3 Ibid., pp. 124-25. 
Living Wage Commission had been at work some months. At the 1926 conference of the party the commission produced its interim report, Socialism in Our Time, on which there was a fairly lengthy debate.

Socialism in Our Time was a short, tightly written document. The break-up of the old order demanded "a conscious and resolute Socialist policy, planned deliberately to carry us through the period of transition from the old to the new civilisation". The ILP wished to make its first attack on poverty. As a matter of social justice, "the workers have the first claim on the wealth of the nation". The achievement of a living income was the first task. Brailsford, in his speech introducing Socialism in Our Time, outlined three reasons for placing such an emphasis on the living wage. In the first place, it was something "which would be intelligible to the simplest man or woman on the verge of politics". Secondly, and following the underconsumptionist argument, a rise in purchasing power would "turn the wheels of industry again". And thirdly, its adoption as a major aim seemed to offer the best chance of linking up the trade-union and political arms of the Labour movement on "an issue which concerned them equally".2

To commence with the living wage was justifiable not only these grounds, however, for it was a demand, Socialism in Our Time claimed, "which has the power, if we follow its logic with courage, to carry us rapidly towards the realisation of a Socialist State". ${ }^{3}$ The effort to secure a living wage for everyone and to ensure that it represented a gain in real earnings contained a logic of its own, which Brailsford had taken pains to state in Socialism for To-Day. Banking and credit, the import of food and raw materials, transport and power, the land and housing were all to be nationalised with the object of maintaining an improved and civilised standard of living. ${ }^{4}$ The criterion for nationalisation, Brailsford pointed out in his speech at the conference, "was not whether industry was bankrupt or prosperous, but whether the possession of that industry would give control over the rest of industry". 5

A major recommendation, which Brailsford had not touched on in Socialism for To-Day, was for a system of family allowances. At the conference Brailsford regarded this recommendation as completing their proposals, for it seemed unlikely to him that any progress towards

1 ILP, Socialism in Our Time (London, 1926), reproduced in ILP, Conference Report 1926, p. 76.

2 Ibid., pp. 78-79.

3 Ibid., p. 76.

4 Ibid., pp. 76-77.

5 Ibid., p. 80. 
a living wage, in its initial stages "would meet with their conception of a civilised level". ${ }^{\text {T }}$ The proposal was that a sum be paid out of direct taxation to the mother for the support of every child until its schooldays were over. Again, the proposal had its humanitarian aspects, but its importance, Brailsford stressed, "was that it began at once the redistribution of national income". ${ }^{2}$ The originator of the idea of family allowances in this context seems to have been Hugh Dalton. ${ }^{3}$ Dalton certainly regarded it from every point of view as "one of the most important proposals which had ever been put to Conference".

"It was a realisation of our first Socialist principle; To each according to his needs. The scheme might be carried into effect in the first Budget of the next Labour Government. There was no difficulty beyond the need to lay taxation on the wealthy classes."4

R. C. Wallhead made the point that "the State already recognised the principle of family allowances - at Buckingham Palace". ${ }^{5}$

There were many criticisms of Socialism in Our Time during the debate. Some argued against the possibility of arriving at a figure for a living wage that everyone could agree to, let alone one that could be enforced. ${ }^{6}$ This, of course, was an argument which could not be conclusively countered, but Frank Wise stated that "in the past every trade union had tried to fix and enforce a minimum wage, restricted by having to look at the circumstances of its own industry at the moment. He saw no outstanding difficulties in doing over a wide area what had been done in a multitude of cases."7 One delegate, W. J. Stimpson, was apprehensive that the Parliamentary Labour Party would not be prepared to follow such a policy should the electorate respond to the scheme by returning a Labour government. He was afraid that "they would, therefore, have built up false hopes in the minds of the people". ${ }^{8}$ Emanuel Shinwell was convinced that a living wage could not be secured from a capitalist society. The question of the living wage was therefore inappropriate. The proper question to be considered was "the conflict between two conceptions of the organisation of society", and Shinwell wanted the proposal referred back for further consideration. ${ }^{9}$

1 Ibid.

2 Ibid.

3 In H. N. Brailsford et al., The I.iving Wage (London, 1926), p. 54, there is an acknowledgement to Hugh Dalton for his help on family allowances.

4LP, Conference Report 1926, p. 82.

5 Ibid., p. 83.

Ibid., pp. 80, 83-84.

7 Ibid., p. 81 .

Ibid., p. 83 .

Ibid., p. 81 . 
By far the most trenchant criticism, however, came from John Strachey, supported by Oswald Mosley. Strachey's point was that there was "no real credit policy". He drew attention to the Birmingham proposals that he and Mosley had drawn up," and suggested that "a proposal which did not include a credit policy when they had taken over the banks was not enough". Without a credit policy they could not hope to "break through that vicious circle of poverty and unemployment which was dominant today". ${ }^{2}$ It is quite true that Socialism in Our Time said no more about credit policy than that, with the banks nationalised and credit under public control, it would then be possible, together with other controls, to direct and reorganise production "for the supply of the workers' needs", ${ }^{3}$ an effort which would be supplemented by the increased production which the payment of family allowances would stimulate. We must be clear, however, what kind of document Socialism in Our Time was. It was a propaganda document designed to rally support for a future Labour government.

"The I.L.P. calls upon all its members to devote themselves unsparingly in Parliament, in their trade unions, in their cooperative societies, in every branch of public life, and in the day-to-day task of propaganda and organisation, to the fulfilment of this policy of transition from Capitalism to Socialism.

Our task is to intensify the challenging spirit within the Labour movement, and to educate the public to understand the need for rapid and fundamental change."4

Though Socialism in Our Time concentrated on one issue, it did demonstrate for the more thoughtful the connexion between this one issue and the many others which were more familiar articles of socialist orthodoxy. However, it was not a matter of Brailsford's unawareness

1 In Revolution by Reason (Birmingham, 1925), Mosley used the language of planning, by which he meant an effort on the part of the state to ensure that sufficient goods and services were produced to cope with the increased demand which an expansion of credit would have stimulated. There is a case for arguing that the term "planning" owes its presence in The Living Wage to the publicity given it by Mosley. If so, it is unlikely that it was due to Mosley's active influence, as during the winter of 1925-26 he was in the United States (O. Mosley, My Life (London, 1970), p. 185). Retrospectively, Mosley is contemptuously dismissive of the Living Wage policy (ibid., p. 220). See Oldfield, op. cit., pp. 228-38.

ILP, Conference Report 1926, p. 86.

3 Ibid., p. 76.

4 Ibid., p. 78. 
of what was involved in a credit policy: $:^{1}$ he had written revealingly, if shortly, in Socialism for To-Day, and had earlier spoken to the theme at the 1924 Labour Party conference, where he successfully moved an amendment on banking and credit to a main resolution dealing with measures to cope with unemployment. ${ }^{2}$ The real reason for the lack of detail in Socialism in Our Time was that detail would have been inappropriate in it: it was a short, punchy statement of a policy which, in Brailsford's words, "would be intelligible to the simplest man or woman on the verge of politics".

This consideration may also help to explain the absence of any specific reference to planning, save for the initial indication that the policy to be pursued during the transition period from the old to the new order should be "planned deliberately", or to the institutional arrangements for giving effect to the policy. These were, in any case, areas which were to be dealt with quite conclusively in The Living Wage. Socialism in Our Time was an interim report of the ILP's Living Wage Commission, and it was approved by the 1926 conference with only two dissentients. ${ }^{3}$

The Living Wage was more than an amplification of Socialism in Our Time: in certain important respects there were additional features which made it a guide both to strategy and to tactics. More than any other document produced by the ILP in the period under discussion it was a comprehensive statement of domestic policy in which, though the overt emphasis was on a living wage, the central argument was for the adoption of full-scale planning.

Both the humanitarian and the underconsumptionist arguments were used in support of the demand for raising the level of wages. Yet, while a living wage for all was the ultimate objective, it was not expected to be immediately realisable, and for this reason emphasis was placed on a living income to be secured by the payment from direct taxation of family allowances. ${ }^{4}$ There was a certain ambivalence

' Mosley has received too much credit in recent years for adding 'to the II.P's preoccupation with redistribution an interest in monetary policy as a means of expanding demand" (R. Skidelsky, Politicians and the Slump, p. 168). Though the preoccupation of the ILP was with redistribution of income, on the Hobsonian argument that this itself would expand demand, Clifford Allen had argued in The Socialist Programme for "an expansion of purchasing power brought about by an increase of bank advances" as a remedy for unemployment (p. 26).

2 Brailsford, Socialism for To-Day, p. 99; Labour Party, Conference Report 1924, pp. 161-66; see also Dowse, op. cit., p. 98.

3 Though Dowse, op. cit., has frankly and avowedly studied the ILP's decline as "a consequence of structural factors which left little room for manoeuvre" (p. ix), it is strange that he entirely ignores The Living Wage, and treats Socialism in Our Time as the final report of the Living Wage Commission.

4 Brailsford et al., The Living Wage, pp. 20-34. 
in regard to the effects of paying a living wage. In one place it is suggested that an expansion of purchasing power would automatically call forth a proportionate increase in production, ${ }^{1}$ yet in other places, and this is the most consistently presented view, consciously directed action is recommended to ensure that greater production would indeed take place, and moreover keep prices stable. The possibility of greater production in part depended on "a due proportion of the purchasing power of the country" being available for mass consumption; but it also depended on "the greater efficiency of existing capital and labour, i.e. upon the reorganisation of industry". ${ }^{2}$

The objective of general price stability could be achieved by controlling the import of food and raw materials through bulk purchase on long-term contracts, ${ }^{3}$ and by the kind of change in overall credit policy which only the nationalisation of the Bank of England could secure. The amount of credit would be expanded or contracted contra-cyclically: booms, with their excessive accumulation of savings, would no longer occur, and neither would slumps, with their high levels of unemployment and underutilisation of industrial capacity. ${ }^{4}$

The major criterion for nationalisation, which Brailsford had noted in his conference speech of the previous April, was here repeated. Nationalisation at this stage should be confined to " "key' industries and services. By a key industry we understand an industry which the community should control, because in some sense it governs the pace and direction of the nation's industrial growth."5 Public control of these key industries was not expected to be sufficient for the purposes of governing the development of industries not to be nationalised. For these industries an Industrial Commission would be set up "which would take under its survey and control every industry which sought its assistance, on the application either of the masters or the men, on the ground that it was unable to pay the minimum wage defined". The Industrial Commission would possess two general powers: "the power to suggest, to promote and ultimately to enforce the amalgamation of businesses" in the interests of greater efficiency; and "the power to create Selling Agencies [...] in cases where commercial disorganisation and excessive competition help to explain an industry's misfortunes". ${ }^{6}$

In addition to securing the objective of general price stability, the

1 Ibid., p. 34.

2 Ibid., pp. 17-18.

3 Ibid., pp. 42-43.

4 Ibid., p. 13

5 Ibid., p. 37.

- Ibid., pp. 38-40. 
banks had an equally important function to perform in relation to the reorganisation of industry. "It is important that considerations of national policy and social utility should govern the direction of the flow of credit as well as its volume." Brailsford, of course, had made this point in Socialism for To-Day, and it had been hinted at in Socialism in Our Time, but here it was stated more forthrightly and with greater realisation of its importance in relation to changes in the distribution of income. The instruments governing the direction of the flow of credit were the joint-stock banks. Their co-operation would be indispensable, once Parliament had adopted "such a policy of national planning and reorganisation as we are advocating". Their general functions would be to "foster the staple industries and to assist the luxury trades to adapt themselves to the change in demand which must result from a change in the distribution of the national income". ${ }^{1}$ In discharging these functions, the joint-stock banks would be assisted and largely directed by a "National Industrial Bank, or Investment Trust".

"This institution would employ the most expert technical advisers and would intervene actively [...] in the higher politics of industry, promoting amalgamations and using the power of massed capital to foster efficiency for the general good. [...] It should be linked up with the Industrial Commission, and would become one of the most powerful means by which the penetration and control of industry can be promoted. [...]

It would, indeed, in association with the Industrial Commission and the Councils of the nationalised services, tend to become the planning and directive centre of the nation's industrial life. Its opinion would be the chief factor in deciding, on grounds of public utility, what private financiers decide today on grounds of gain - whether this industry or the other shall expand, whether the needs of home agriculture shall have precedence over some foreign or colonial call for capital, whether a source of raw material should be expanded, or a new invention rapidly utilised."2

The demand for a living wage thus led inexorably to the demand for a comprehensive system of planning in which the central institutions of the state would control the production and investment decisions of the economy in accordance with social purposes. "In the process of raising the general standard of life", The Living Wage continued, "we should attain much more than we set out to win." The policy had the merit, moreover, "of making a simple and concrete appeal to the

1 Ibid., p. 19.

2 Ibid., p. 46. 
average worker and his wife. Family Allowances and a Living Wage touch them in their daily experience of life. Once their attention is concentrated on these things, the rest of the scheme will enlist their defensive instincts." 1

What is of interest about The Living Wage is the fact that its prescriptions for dealing with the economic problems of the time led to the self-conscious development of a concept of planning. The term denoted comprehensiveness of approach as well as the need for central direction and co-ordination. It brought to the fore the central control of decisions on investment spending as the means for shaping the future economic and social structure of the country; and, for a country as dependent on foreign trade as Britain, it emphasised the need for control of the supply and prices of imported food and raw materials. In these respects - control of investment, and of imports - The Living Wage was markedly different from Labour and the New Social Order, the Labour Party's 1918 policy statement. ${ }^{2}$ There is a further difference between the two documents. The Living Wage dealt only with the transition from the old to the new order, and it therefore wrote about planning only in this context. There was no indication, as there had been in Labour and the New Social Order, that the manner of managing the new order would be any different from the means used to effect the transition. The end-state may have been some elevated condition of fraternal co-operation, but the emphasis was on the communal organisation of economic affairs to achieve the more limited, yet still fundamental, aim of a living income for all.

Little attention was paid in The Living Wage to that other issue which had so exercised the minds of ILP members in the early 1920's: workers' control. A separate ILP inquiry commission on industrial policy had been investigating this, and had made recommendations regarding industrial self-government for the consideration of the trade unions, and of the 1926 party conference. ${ }^{3}$ It was completely overshadowed, however, by the report of the Living Wage Commission. From the point of view of the purposes set out in The Living Wage, a preoccupation with workers' control smacked of the luxury of idealism. A portent of the fall from prominence of such policies was Attlee's successful insistence, at the 1922 party conference, on the need to include in the party's constitution an undertaking to establish some central co-ordinating authority. If everything did not follow from this, the line of advance was at least indicated.

1 Ibid., pp. 52-53.

'See Oldfield, "The Labour Party and Planning", loc. cit., pp. 52-53.

s ILP, Conference Report 1926, pp. 58-59. 